\title{
Perbuatan catcalling dalam perspektif hukum positif
}

\author{
Tauratiya ${ }^{\mathrm{a}, 1, *}$ \\ a IAIN Syaikh Abdurrahman Siddik Bangka Belitung. Jl. Raya Petaling, Kab. Bangka, Prov. Bangka Belitung, Indonesia \\ ${ }^{1}$ tauratiya@iainsasbabel.ac.id * \\ * Korespondensi Penulis
}

\section{ARTICLE INFO}

Article history

Received June 26, 2020

Revised June 26, 2020

Accepted June 27, 2020

Available Online June 30, 2020

Keywords

Catcalling

Pelecehan seksual

Hukum

\section{ABSTRACT}

Catcalling as one of the actions that violates morality and categorized as criminal act oftenly unnoticed, because this action is done spontaneously. Many societies in Indonesia don't realize that they are victim or even perpetrator of catcalling act. This is because of the lack of understanding in society about the catcalling act itself. This act unwittingly has reduced a person's right, like the right to have a peaceful life, the right to feel safe while doing activities, the right to feel at ease in building life and living and happy physically and mentally in society living, so that this act needs to be vanished. However, the perpetrator of this catcalling act is hard to be caught to the realm of law until now as long as they didn't do physical violence to the victim, but in this case there needs to be an emphasis to stop this catcalling act and to entangle as well as to make the perpretators aware of this act, and also by giving the understanding about catcalling law to the public, especially the victims could bring this case to attain the justice for each victim. Catcalling act in Indonesia categorized as criminal act and contradictive to law and morality. Law enforcement regarding the catcalling act in Indonesia so far haven't got any legal certainty, even the handling and resolving of this catcalling problem could not be done decisively. Catcalling victims are still having trouble getting their justice. So far the protection of catcalling victims regulated in Law No. 39 of 1999 on Human Rights, and Law No. 31 of 2014 on Changes to Law No. 13 of 2006 on Victim and Witness Protection as the legal basis. While for perpetrator of catcalling act could be charged with Article 281 Item (2) and Article 315 on Criminal Code and Article 34 juncto Article 8, Article 35 juncto Article 9 Law No. 34 of 2008 on Pornography. 
Catcalling sebagai salah satu perbuatan atau tindakan yang bertentangan dengan kesusilaan dan dikategorikan sebagai suatu tindak pidana seringkali tidak terperhatikan, hal ini dikarenakan tindakan atau perbuatan tersebut dilakukan secara spontan. Banyak kalangan masyarakat di Indonesia yang tidak menyadari bahwa dirinya adalah korban atau bahkan pelaku perbuatan catcalling. Hal ini dikarenakan kurangnya pemahaman terhadap masyarakat tentang catcalling itu sendiri. Perbuatan catcalling tanpa sadar telah mengurangi hak-hak asasi seseorang, seperti hak untuk merasakan kehidupan yang damai, hak untuk merasa aman dalam beraktifitas, hak untuk merasa tentram membangun hidup dan kehidupan serta bahagia lahir dan batin dalam kehidupan bermasyarakat, sehingga keberadaan catcalling ini penting untuk dihilangkan. Akan tetapi, Pelaku perbuatan catcalling sampai saat ini masih sulit untuk dijerat keranah hukum selama tidak melakukan kekerasan fisik terhadap korban, tetapi dalam hal ini perlu adanya penekanan untuk menghentikan perbuatan catcalling dan menjerat sekaligus menyadarkan pelaku catcalling, serta dengan memberikan pemahaman tentang aturan hukum catcalling kepada publik, terutama korban dapat membawa kasus ini guna merandapatkan keadilan bagi hak asasi masing-masing korban. Catcalling di Indonesia dikategorikan kedalam salah satu perbuatan pidana atau suatu tindak pidana dan bertentangan dengan hukum dan kesusilaan. Penegakan hukum terhadap perbuatan catcalling di Indonesia sejauh ini belum memiliki kejelasan dan kepastian hukum, bahkan penanganan dan penyelesaian terhadap perkara catcalling ini tidak bisa diselesaikan secara tegas. Korban catcalling masih sulit untuk mendapatkan keadilan bagi dirinya. Sejauh ini perlindungan terhadap korban perbuatan catcalling diatur dalam Undang-Undang Nomor 39 Tahun 1999 Tentang Hak Asasi Manusia (HAM) dan Undang-undang Nomor 31 Tahun 2014 Tentang Perubahan Atas Undang-Undang Nomor 13 Tahun 2006 Tentang Perlindungan Saksi dan Korban sebagai dasar hukumnya. Sedangkan, Sedangkan bagi pelaku perbuatan catcalling dapat dikenakan Pasal 281 butir (2) dan Pasal 315 pada KUHP dan Pasal 34 j.o Pasal 8, dan Pasal 35 j.o Pasal 9 Undang-Undang Nomor 44 Tahun 2008 Tentang Pornografi.

This is an open access article under the CC-BY-SA license.

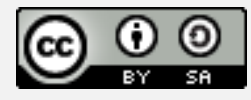

\section{Pendahuluan}

Berbagai macam bentuk pelecehan dewasa ini semakin meningkat. Umumnya perempuan yang sering menjadi korban pelecahan, akan tetapi tidak menutup kemungkinan laki-laki pun bias menjadi korban dari tindak pelecehan. Pelecehan yang terjadi tidak hanya didapati di ruang tertutup saja, melainkan sekarang banyak tindakan pelecehan yang dialami kaum hawa dilakukan di ruang public atau terbuka, salah satunya yang paling sering ditemui adalah perbuatan catcalling.

September 2019, melalui situs tribunnews.com diberitakan bahwa Polisi menangkap Pelaku perbuatan catcalling disalah satu lampu merah yang ada di Bekasi, dalam kasus ini korban yang tidak lain adalah seorang perempuan berusia 24 tahun dan pelaku adalah seorang laki-laki berusia 37 tahun menyelesaikannya perkara ini dengan jalan damai. Selanjutnya di tahun 2020, baru-baru ini Hanna Al Rashid salah satu aktris sekaligus Duta SDG untuk Kesetaraan Gender yang dikenal aktif menyuarakan kesetaraan gender, terutama yang berkaitan dengan pelecehan menjadi korban catcalling oleh driver Ojek Online di kawasan Cipete, Jakarta Selatan.

Catcalling sebagai salah satu tindakan atau perbuatan yang bertentangan dengan kesusilaan seringkali tidak terperhatikan, hal ini dikarenakan tindakan atau perbuatan tersebut dilakukan secara spontan. Banyak kalangan masyarakat di Indonesia yang tidak menyadari bahwa dirinya adalah korban atau bahkan pelaku perbuatan catcalling. Hal ini dikarenakan kurangnya pemahaman terhadap masyarakat tentang catcalling itu sendiri. 
Banyak yang beranggapan bahwa catcalling adalah suatu perbuatan yang lumrah dan merupakan hal yang wajar dilakukan, bahkan faktanya banyak yang menganggap catcalling sebagai suatu pujian atau candaan yang disampaikan seseorang di tempat-tempat umum. Akan tetapi, nyatanya tindakan atau perbuatan tersebut termasuk salah satu bentuk gangguan di jalan (street harassement) dan tindakan pelecehan seksual secara verbal atau termasuk kategori pelecehan seksual nonfisik yang terjadi kepada seseorang tanpa kesukarelaan orang tersebut (Kinasih, 2007).

Pelecehan seksual dalam naskah akademik suatu Rancangan Undang-Undang (RUU) Republik Indonesia tentang Penghapusan Kekerasan Seksual (PKS) diartikan sebagai segala perbuatan baik secara fisik maupun bukan fisik, menjadikan organ seksual korban sebagai objek sasaran, dalam prakteknya dilakukan dengan panggilan-panggilan yang tidak diinginkan, gerakan atau isyarat yang menunjukkan secara terang-terangan adanya keinginan yang bersifat seksual sehingga menimbulkan rasa tidak nyaman dan terancam, tersinggung, merasa dilecehkan martabatnya, bahkan mungkin akan berdampak pada kesehatan dan keselamatan korban (Naskah Akademik Rancangan UndangUndang (RUU) Tentang Penghapusan Kekerasan Seksual (PKS), 2017).

Catcalling di Amerika, Inggris, dan negara-negara Barat lainnya menjadi suatu hal yang sangat krusial, catcalling biasanya dapat berupa kalimat pujian iseng seperti "You look so pretty?", "Hi, sexy girl", hingga kalimat yang mengerikan dan jelas bersifat seksual seperti "Nice tits!", "Hi girl, come with me?", bahkan sentuhan-sentuhan berlebihan. Sedangkan, di Indonesia, catcalling yang terjadi biasanya berbentuk bebunyian suara atau siulan-siulan tidak sopan, kalimat godaan dan sapaan absurd seperti "Hai, cantik, mau ke mana?", "Cewek, sendirian aja, nih? Mau ditemenin, nggak?", atau berbentuk perhatian berlebihan yang tidak masuk akal dan memanggil dengan kalimat bernada menggoda seperti "Kok, cemberut aja, Neng? Lagi sedih ya?", "Kayaknya boleh juga nih". Biasanya jika korban catcalling ini tidak merespon atau bersikap acuh kepada pelaku, maka catcalling akan berlanjut menjadi komentar-komentar dengan kalimat seperti "Ih, sombong banget, sih?”, “Jangan malu-malu dong”, dan kalimat lainnya yang bersifat melecehkan.

merasakan kehidupan yang damai, hak untuk merasa aman dalam beraktifitas, hak untuk merasa tentram membangun hidup dan kehidupan serta bahagia lahir dan batin dalam kehidupan bermasyarakat, sehingga keberadaan catcalling ini penting untuk dihilangkan. Akan tetapi, Pelaku perbuatan catcalling sampai saat ini masih sulit untuk dijerat keranah hukum selama tidak melakukan kekerasan fisik terhadap korban, tetapi dalam hal ini perlu adanya penekanan untuk menghentikan perbuatan catcalling dan menjerat sekaligus menyadarkan pelaku catcalling, serta dengan memberikan pemahaman tentang aturan hukum catcalling kepada publik, terutama korban dapat membawa kasus ini guna merandapatkan keadilan bagi hak asasi masing-masing korban.

\section{Metode}

Metode penelitian yang digunakan ialah metode yuridis normative. Yuridis normative merupakan metode penelitian hukum dengan menggunakan data sekunder sehingga dapat disebut pula dengan penelitian kepustakaan atau library research. Penelitian ini didukung dengan data sekunder yang penulis peroleh melalui bahan kepustakaan seperti peraturan Perundang-Undang, buku-buku, literature, artikel, koran, majalah, atau bahkan melalui media elektronik yang digunakan untuk memperoleh bahan-bahan yang bersifat teoritis dan dipergunakan sebagai dasar dalam penelitian. Kajian pustaka ini akan membahas perbuatan catcalling dalam perspektif hukum positif.

\section{Hasil dan Pembahasan}

Catcalling dalam bahasa Indonesia bukanlah diartikan dengan panggilan kucing, tetapi lebih mengarah kepada kalimat godaan verbal, yaitu suatu tindakan berbentuk siulan atau kalimat godaan yang dilontarkan seseorang kepada orang lain, pada umumnya adalah wanita yang lewat dimuka publik. Dalam kamus Oxford Dictionary, catcalling diartikan sebagai bebunyaian tidak sopan seperti siul-siulan, panggilan, dan perkataan atau komentar yang bersifat seksual, bahkan terkadang dilakukan bersamaan dengan tatapan mata yang bersifat melecehkan sehingga membuat seseorang menjadi tidak nyaman.

Catcalling di Indonesia dikategorikan kedalam salah satu perbuatan pidana atau suatu tindak pidana dan bertentangan dengan hukum dan kesusilaan. Perbuatan pidana merupakan suatu tindakan atau perbuatan yang dilarang untuk dilakukan karena melanggar norma hukum dan memiliki 
ancaman sanksi terhadap orang yang melanggar aturan tersebut, larangan ini ditujukan kepada perbuatannya dan sanksi ditujukan kepada pelaku perbuatan atau tindak pidana (Moeljatno, 2002). Dengan kata lain, setiap orang yang melakukan perbuatan atau tindak pidana catcalling akan mendapatkan sanksi hukum.

Catcalling dikategorikan sebagai suatu perbuatan pidana karena memenuhi unsur-unsur dari suatu tindak pidana yang menurut Prof. Simons unsur-unsur tersebut yaitu: Adanya suatu perbuatan yang dilakukan oleh manusia, diancam pidana, unsur melawan hukum, dilakukan dengan kesalahan, dan orang yang mampu beratnggung jawab (Ruba'i, 2014).

Perbuatan atau tindakan catcalling memenuhi unsur pertama dari suatu tindak pidana, karena catcalling merupakan perbuatan manusia, dimana perbuatan yang dilakukan adalah melontarkan kalimat bermuatan pornografi atau perilaku yang memberikan rasa tidak nyaman terhadap orang lain, misalnya bersiul, mengeluarkan bunyi atau suara yang memancing seksualitas, atau berekspresi tidak pantas seperti menyipitkan mata dan tersenyum menggoda. Catcalling merupakan pelecehan seksual secara verbal, karena termasuk perbuatan asusila dan mengandung muatan pornografi maka dapat diancam dengan pidana tentang kejahatan terhadap kesusilaan.

Tindakan Catcalling dapat dikatakan melawan hukum karena mengganggu dan mengurangi hak asasi manusia (HAM) orang lain, dimana dalam hal ini perbuatan atau tindakan yang mengganggu dan mengurangi hak asasi orang lain melanggar hukum. Unsur kesalahan dalam perbuatan catcalling ini diantaranya ialah kemampuan dari diri pelaku kejahatan tersebut untuk bertanggung jawab terhadap semua tindakan yang dilakukannya, hubungan yang kuat antara pembuat dengan perbuatannya yang dilakukan karena kesengajaan atau kealpaan dan tidak terdapat alasan penghapus kesalahan seperti alasan pemaaf. Pertanggung jawaban dari pelaku catcalling berkaitan erat dengan kesalahan yang pelaku buat. Seseorang dikatakan mampu untuk dimintakan pertanggungjawabnnya apabila tidak ada lagi alasan pembenar dan/atau alasan pemaaf dari perbuatan yang dilakukannya. Catcalling atau pelecehan seksual secara verbal membuat korbannya merasakan ketidak nyamanan, terganggu, ketakutan, trauma bahkan gangguan secara mental dari keadaan seperti itu.

\subsection{Catcalling dalam Perspektif Hukum Positif}

Penegakan hukum terhadap perbuatan catcalling di Indonesia sejauh ini belum memiliki kejelasan dan kepastian hukum, bahkan penanganan dan penyelesaian terhadap perkara catcalling ini tidak bisa diselesaikan secara tegas. Korban catcalling masih sulit untuk mendapatkan perlindungan dan keadilan bagi dirinya. Sejauh ini perlindungan terhadap korban perbuatan catcalling diatur dalam Undang-Undang Nomor 39 Tahun 1999 Tentang Hak Asasi Manusia (HAM) dan Undang-undang Nomor 31 Tahun 2014 Tentang Perubahan Atas Undang-Undang Nomor 13 Tahun 2006 Tentang Perlindungan Saksi dan Korban sebagai dasar hukumnya.

Hak asasi manusia yang dijunjung tinggi di Indonesia diatur secara jelas dan tegas didalam konstitusi Negara yaitu Undang-Undang Dasar 1945 (UUD 1945). Sebagai dasar hukum tertinggi, UUD 1945 menjamin perlindungan, pemajuan, penegakan dan pemenuhan HAM warga negaranya, serta harus dihormati dan dijamin pelaksanaannya oleh negara maupun kelompok individu. Didalam Pasal 28B ayat (2) UUD 1945, Negara menjamin setiap hak asasi manusia atas kelangsungan hidup, tumbuh, dan berkembang serta berhak atas perlindungan dari kekerasan diskriminasi. Jadi dalam hal ini jelas bahwa korban catcalling juga harus mendapatkan perlindungan yang sama dengan yang lainnya sebagaimana yang diatur dalam undang-undang tersebut.

Ketentuan Pasal 1 angka 3 Undang-undang Nomor 31 Tahun 2014 Tentang Perubahan Atas Undang-Undang Nomor 13 Tahun 2006 Tentang Perlindungan Saksi dan Korban (PSK) memberikan pengertian korban adalah orang yang mengalami penderitaan secara fisik, mental, dan/atau kerugian ekonomi akibat dari suatu tindak pidana. Ketentuan pasal tersebut menegaskan bahwa korban perbuatan catcalling termasuk orang yang mengalami kerugian baik secara mental maupun psikisnya karena perbuatan catcalling oleh pelaku menimbulkan rasa malu, terganggu dan ketakutan bagi korban. Korban perbuatan catcalling ini termasuk kedalam kategori korban langsung, dimana memiliki karakteristik korban ialah setiap orang individu ataupun kolektif, menderita suatu kerugian baik fisik, mental, dan emosionalnya, serta mendapatkan penindasan terhadap hak asasi manusia yang disebabkan oleh adanya perbuatan yang dianggap suatu tindak pidana dalam hukum pidana dan disebabkan oleh adanya penyalahgunaan kekuasaan (Ariyanti, 2019). 
Secara garis besar, korban dari suatu tindakan catcalling menurut Undang-Undang Perlindungan Saksi dan Korban berhak mendapatkan perlindungan dibidang keamanan; dibebaskan untuk memilih jenis perlindungan yang akan diberikan; dibebaskan dari segala tekanan untuk memberikan keterangan; terlindungi dari segala jenis pertanyaan bersifat menjerat; mendapatkan informasi yang jelas mengenai perkembangan perkara yang sedang berlangsung; mendapatkan informasi perihal putusan pengadilan pelaku; diberitahu apabila terpidana bebas dari segala tuntutan; memperoleh identitas baru; diberikan kediaman baru, mendapat jaminan penggantian biaya ganti rugi perihal transportasi, diberikan nasihat hukum dan juga mendapatkan biaya bantuan untuk menyokong kehidupan sementara (Burhan, 2019). Masyarakat dapat berperan dan membantu memberikan dukungan kepada korban untuk memulihkan nama baik, serta memulihkan keseimbangan batin korban dari perbuatan catcalling (Kobandaha, 2017).

Adanya kekosongan hukum atau aturan terhadap perbuatan catcalling ini membuat para penegak hukum harus menggali hukum dan melakukan penafsiran dari beberapa aturan yang ada dan berkaitan dengan tindak perbuatan catcalling ini. Saat ini, dasar yang digunakan penegak hukum dalam menangani dan menjerat pelaku kasus catcalling yaitu dengan menggabungkan pasal-pasal dalam Kitab Undang-undang Hukum Pidana (KUHP) dan Undang-Undang Nomor 44 Tahun 2008 Tentang Pornografi. Pasal-pasal dalam KUHP yang berkaitan dan dapat dipergunakan sebagai dasar untuk menyelesaikan kasus tindak pidana catcalling ini, yaitu Pasal 281 butir (2) KUHP dan Pasal 315 KUHP. Pasal 281 butir (2) KUHP mengatur bahwa apabila ada seseorang yang dengan sengaja di depan orang lain di luar kehendak orang tersebut, kemudian melakukan suatu tindakan atau perbuatan yang bertentangan atau melanggar kesusilaan, maka dapat dipidana penjara ataupun denda.

Pengertian melanggar kesusilaan yang terdapat dalam pasal tersebut diatas menitikberatkan kepada pelanggaran terhadap kesopanaan dibidang seksual, dimana perbuatan atau tindakan tersebut pada umumnya akan menimbulkan perasaan malu, geli, jijik atau bahkan terangsangnya hawa nafsu seksual seseorang. Menurut S.R. Sianturi, apakah suatu perbuatan melanggar kesusilaan atau tidak maka perlu memperhatikan sudut kebiasaan setempat, hal ini dikarenakan cara pandang antara satu tempat dengan tempat lainnya yang dapat berbeda-beda (Sianturi, 1983).

Secara yuridis sangatlah perlu diperhatikan kebiasaan setempat, hal ini disebabkan ajaran melawan hukum yang material dianut hukum pidana Indonesia, dimana harus memperhatikan apakah perbuatan atau tindakan yang dilkukan oleh masyarakat dipandang sebagai patut pidana. Dalam menentukan dan memutuskan apakah perbuatan itu telah melanggar kesusilaan atau tidak, Hakim perlu memperhatikan pandangan yang berbeda-beda antara satu masyarakat dengan masyarakat lainnya di Indonesia tentang kebiasaan setempat masyarakat (Kolompoy, 2015).

Ketentuan Pasal 315 KUHP menegaskan dan mengatur bahwa setiap penghinaan yang dilakukan seseorang dengan sengaja terhadap orang lain dihadapan publik (muka umum) secara lisan atau tulisan, atau dihadapan orang itu sendiri secara lisan maupun perbuatan, atau melalui surat yang dikirimkan dan diterima orang yang bersangkutan dikategorikan sebagai tindak pidana penghinaan ringan dengan hukuman atau sanksi pidana berupa penjara atau denda. Akan tetapi, penggunaan Pasal 315 KUHP untuk menyelesaikan perkara catcalling kurang tepat, karena perbuatan catcalling dianggap bukanlah suatu penghinaan, mengingat penghinaan tidak jauh dari penistaan yang berupa merendahkan atau celaan yang dapat berupa kritikan (Marpaung, 2010), sedangkan catcalling merupakan suatu pujian yang memberikan rasa tidak nyaman, merasa terganggu, bahkan rasa ketakutan kepada si penerima pujian mengingat pujian tersebut diberikan oleh orang lain yang tidak dikenal dan terkadang dilontarkan dengan nada menggoda.

Selain dalam KUHP, Pasal 35 j.o Pasal 8, dan Pasal 35 j.o Pasal 9 Undang-undang Nomor 44 Tahun 2008 Tentang Pornografi juga dapat digunakan sebagai dasar untuk menyelesaikan perkara catcalling. Pasal 1 angka 1 Ketentuan Umum dalam Undang-undang pornografi memberikan definisi:

Pornografi adalah gambar, sketsa, ilustrasi, foto, tulisan, suara, bunyi, gambar bergerak, animasi, kartun, percakapan, gerak tubuh, atau bentuk pesan lainnya, melalui berbagai bentuk media komunikasi dan/atau pertunjukan di muka umum, yang memuat kecabulan atau ekploitasi seksual yang melanggar norma kesusilaan dalam masyarakat. 
Dari ketentuan diatas terlihat bahwa perbuatan catcalling memenuhi unsur-unsur yang terkandung dalam pasal tersebut, seperti suara, bunyi, percakapan atau kalimat-kalimat, gerak tubuh, atau bentuk lainnya yang dilakukan di muka public dan memuat unsur kecabulan dan/atau eksploitasi seksual yang bersifat melanggar norma kesusilaan.

Ketentuan Pasal 34 j.o Pasal 8 Undang-undang Pornografi secara garis besar mengatur bahwa akan memberikan sanksi pidana penjara dan/atau denda bagi setiap orang dengan unsur kesengajaan atau atas persetujuannya menjadikan dirinya sendiri sebagai objek atau bahan publik yang mengandung muatan pornografi. Selanjutnya, ketentuan Pasal 35 j.o Pasal 9 Undang-undang Pornografi menjelaskan bahwa akan diberikan pidana penjara dan/atau denda bagi setiap orang yang menjadikan orang lain sebagai objek atau bahan publik yang mengandung muatan pornografi. Akan tetapi, penggunaan Pasal-pasal dalam Undang-undang Pornografi untuk menyelesaikan kasus catcalling ini sesungguhnya tidak menjamin kepastian hukum, hal ini dikarenakan penekanan terhadap keempat pasal tersebut hanyalah "dilarang menjadikan diri sendiri atau orang lain sebagai objek atau model yang mengandung muatan pornografi dan bertentangan dengan kesusilaan", perbuatan seperti apa yang dilarang tidak diatur secara tegas dan jelas.

\section{Simpulan}

Catcalling merupakan suatu perbuatan atau tindakan pidana yang melanggar kesusilaan dan pada dasarnya merupakan pelecehan seksual secara verbal. Pelaku perbuatan catcaling memberikan perhatian yang tidak diinginkan kepada orang lain (korban) diluar kehendak orang tersebut dengan cara memberikan siulan, komentar, ucapan dan/atau tindakan yang bernuansa seksual sehingga membuat orang yang menjadi korban merasakan ketidak nyamanan, terganggu, ketakutan, trauma bahkan gangguan secara mental dari keadaan seperti itu. Belum adanya dasar hukum yang jelas dan tegas di Indonesia untuk menyelesaikan kasus catcalling ini menyebabkan tidak adanya kepastian hukum atas perbuatan atau tindakan tersebut. Penyelesaian terhadap kasus tindak pidana perbuatan catcalling di Indonesia sejauh ini masih menggunakan dasar hukum gabungan dari beberapa aturan yang sudah ada, dasar hukum bagi korban perbuatan catcalling yaitu dalam Undang-undang Nomor 31 Tahun 2014 Tentang Perubahan Atas Undang-Undang Nomor 13 Tahun 2006 Tentang Perlindungan Saksi dan Korban, dan Undang-Undang Nomor 39 Tahun 1999 Tentang Hak Asasi Manusia (HAM). Sedangkan bagi pelaku perbuatan catcalling dapat dikenakan Pasal 281 butir (2) dan Pasal 315 pada KUHP, serta Pasal 34 j.o Pasal 8, dan Pasal 35 j.o Pasal 9 Undang-Undang Nomor 44 Tahun 2008 Tentang Pornografi. Meskipun pasal-pasal dalam peraturan tersebut dapat dijadikan dasar hukum untuk perbuatan catcalling tetapi belum mampu memberikan keadilan bagi korban dan menjamin kepastian hukum secara maksimal. Hal ini menunjukkan bahwa terdapat aturan dalam hukum positif di Indonesia yang mengatur tindakan catcalling meskipun bukan aturan khusus yang mengatur perbuatan atau tindakan catcalling, tetapi sampai detik ini masih ada pro kontra terhadap penggunaan pasal-pasal tersebut guna mempidana pelaku. Kekosongan hukum atau aturan tentang perbuatan catcalling harus segara dibentuk untuk mengurangi terjadinya perbuatan catcalling dimasyarakat. Belum adanya suatu aturan dan putusan pengadilan atau doktrin para ahli hukum Indonesia terhadap pemilihan pasal yang dapat digunakan untuk mempidanakan pelaku, membuat lemahnya kepastian hukum terhadap perbuatan atau tindakan tersebut. Harus adanya dasar hukum yang sesuai sehingga pelaku perbuatan catcalling mendapat hukuman yang setimpal dan korban pun mendapatkan keadilan. Kasus catcalling sangat penting untuk dibahas, karena di Indonesia hal ini masih dianggap sangat biasa dan lumrah, padahal catcalling bisa berdampak sangat besar kepada korban. Perlu dilakukan sosialisasi dan pemahaman kepada masyarakat terhadap perbuatan atau tindakan catcalling yang yang tidak lain adalah suatu tindak pidana pelecehan secara verbal agar dapat menghentikan perbuatan ini terus-menerus terjadi dan dilakukan di muka umum.

\section{Daftar Pustaka}

Ariyanti, V. (2019). Konsep Perlindungan Korban dalam Sistem Peradilan Pidana Nasional dan Sistem Hukum Pidana Islam. Al-Manahij: Jurnal Kajian Hukum Islam, 13(1), 33-48.

Burhan, A. A. (2019). Pelaksanaan undang-undang nomor 31 tahun 2014 tentang perlindungan saksi dan korban di polres kota kendari (studi di polres kota kendari). Dinamika: Jurnal Ilmiah Ilmu Hukum, 25(13). 
Kinasih, S. E. (2007). Penegakan HAM dan Perlindungan terhadap Korban Pelecehan Seksual. Jurnal Masyarakat Kebudayaan Dan Politik.

Kobandaha, M. (2017). Perlindungan hukum terhadap anak korban kekerasan dalam rumah tangga dalam sistem hukum di indonesia. Jurnal Hukum UNSRAT, 23(8).

Kolompoy, G. P. (2015). Eksistensi Tindak Pidana Pelanggaran Kesusilaan Di Depan Umum (Pasal 281 Kitab Undang-Undang Hukum Pidana). Lex Crimen, 4(7).

Marpaung, L. (2010). Tindak pidana terhadap kehormatan. Sinar Grafika.

Moeljatno, S. H. (2002). Asas-asas Hukum Pidana. Rineka Cipta, Jakarta.

Naskah Akademik Rancangan Undang-Undang (RUU) Tentang Penghapusan Kekerasan Seksual (PKS), 24 (2017). http://www.dpr.go.id/doksileg/proses1/RJ1-20170307-091105-5895.pdf

Ruba'i, M. (2014). Buku Ajar Hukum Pidana. Cetakan Pertama, Malang: Bayumedia Publishing.

Sianturi, S. R. (1983). Tindak pidana di KUHP berikut uraiannya. Alumni AHM-PTHM. 